\title{
Penerapan play therapy dalam mengembangkan interaksi sosial siswa di SMPN 8 Kota Jambi
}

\author{
$\underline{\text { Rasimin }}^{*}$, Affan Yusra ${ }^{2}$ \\ 1,2 Bimbingan dan Konseling, FKIP, Universitas Jambi \\ rasimin.fkip@unja.ac.id
}

$\begin{array}{ccc}\text { First received: } & \text { Revised: } & \text { Final Accepted: } \\ 17 \text { July } 2021 & 22 \text { September } 2021 & 19 \text { Oktober } 2021\end{array}$

\begin{abstract}
Abstrak
Pengabdian ini bertujuan untuk melihat peranan play therapy dalam mengembangkan interaksi siswa padaSMP 8 kota jambi. Pada kegiatan pelaksanaan PKM ini menggunakan setting klasikal dengan menggunakan play therapy dalam mengembangkan interaksi sosial sisw a melalui metode berikut: 1) Metode Sosialisasi: Melalui metode ini dilakukan proses penanaman atau transfer kebiasaan pada satu generasi kepada generasi berikutnya bisa melalui bentuk individual, kelompok dan masyarakat. Metode ini digunakan untuk memberi beberapa penjelasan tentang interaksi sosialdan panduan play therapy, sertajejak pendapat.2) Metode play therapy: Metode ini dikembangkan dengan dasar konsep yang telah matang, Melalui metode ini siswa dilatih untuk berkomunikasi dengan menggunakan bahasa y ang baik dalam melakukan kerja sama dan melatih kontak sosial antar siswa. Adapunhasildalam PKM dan hasil dari kegiatan PKM ini juga terlihat dalam praktik dan workshop siswa sangat tertarik dengan metode ini karena dalam metode ini tidak hanya menekankan pada pembentukan dinamika interaksi sosial namun juga menekankan pada membangun dinamika anggota kelas sehingga dalam pelaksanaan peserta layanan memperoleh kemampuan dinamika dalam mengembangkan interaksi sosial. Adapun kesimpulan dari PKM ini dapat meningkatkan Interaksi sosial sisw a melalui metode play therapy.
\end{abstract}

Kata Kunci: Play Therapy, interaksi sosial

\begin{abstract}
At SMP 8 Jambi City, this program aims to investigate the function of play therapy in the development of student interaction. The PKM implementation activity employs a traditional setting to develop kids' social relationships through play therapy utilizing the following methods: 1) Socialization Approach: This method can be used to name or transfer habits from one generation to the next. It can be used in individual, group, or community settings. This strategy is utilized to explain social interaction and play treatment principles, as well as to conduct opinion polls. 2) Play treatment approach: This method was created using a well-developed concept. Students are taught to communicate using appropriate language while cooperating and exercising social touch through this strategy. Students are extremely interested in this approach since it not only stresses the construction of dynamics of social contact but also emphasizes the building of dynamics of class members, so that during its implementation, service participants learn dynamic abilities. in establishing social connections. Through the use of play therapy, the conclusion of this PKM can increase kids' social interaction.
\end{abstract}

Keywords: Play Therapy, social interaction 
Penerapan play therapy.......- Rasimin, Affan Yusra

\section{PENDAHULUAN}

Siswa sekolah menengah pertama merupakan remaja yang sedang dalam proses berkembang ke arah kematangan dan kemandirian baik secara pribadi maupun sosial, dalam proses perkembangan tersebut seorang siswa memerlukan interaksi sosial yang baik dengan lingkungan yang ada (Marimbuni et al., 2017). Lingkungan sekolah merupakan satu wadah dalam mengembangkan interaksi sosial siswa. Interaksi sosial merupakan hubungan timbal balik antara dua individu atau lebih, dan cara individu memberikan respon terhadap orang-orang di sekitarnya dan hubungan timbal balik dari respon yang di berikan kepada individu-individu terhadap dirinya timbal balik itu terhadap dirinya dan lingkungan sekitarnya (Dwistia et al., 2013). Agar interaksi sosial berjalan dengan baik perlu adanya syarat-syarat yang perlu di penuhi.

Sumarno, (2008:4) "Syarat terjadinya interaksi sosial ada dua yakni kontak sosial dan komunikasi". Kontak sosial akan terjadi jika hubungan antara satu pihak dengan pihak yang lain yang merupakan awal terjadinya interaksi sosial, setiap pihak tersebut saling berinteraksi antara satu baik secara langsung dan tidak langsung. Sedangkan. Kemampuan dalam mengirimkan pesan atau informasi dengan baik, kemampuan menjadi pendengar yang baik, serta kemampuan atau keterampilan dalam menggunakan media atau audio visual merupakan bagian yang sangat penting dalam melaksanakan komunikasi yang efektif. Namun akhir-akhir ini interaksi sosial siswa satu sama yang lain secara kontak langsung sudah mulai memudar, hal ini disebabkan oleh perkembangan teknologi yang sangat pesat seperti smart phone yang menimbulkan efek seperti kecanduan game, individualis, tidak peduli dengan lingkungan. Berdasarkan kutipan dari sumber berita nasional radarbogor.id tanggal 19 Februari 2020 tentang 85 Persen Pelajar "Kecanduan" Berdasarkan survei dari Hewlett-Packard (HP) dan Universitas Paramadina, didapatkan jika 85 persen siswa "kecanduan" menggunakan ponsel saat berada di kelas tanpa sepengetahuan gurunya. Hal ini didukung dengan hasil penelitian yang dilakukan Witarsa dkk (2018), menjelaskan Ketergantungan terhadap gadget pada anak disebabkan karena lamanya durasi dalam menggunakan gadget. Bermain gadget dengan durasi yang cukup panjang dan dilakukan setiap hari, bisa membuat anak berkembang ke arah pribadi yang antisosial.

Berdasarkan hasil penyebaran instrumen dan wawancara dengan guru pada tanggal 17 di SMPN 8 Kota Jambi terlihat fenomena yang demikian. Hal ini terjadi dikalangan siswa SMPN 8 di Kota Jambi banyak yang menggandrungi ponsel karena fitur- fitur yang ada di dalamnya. Dalam beberapa fitur tersebut bayak muncul gaya komunikasi kurang baik dan mencontoh kegiatan kotak sosial yang kurang baik, seperti komunikasi secara langsung dan tidak langsung sering menggunakan bahasa yang kurang santun dan kontak sosial yang melanggar norma yang telah berlaku di masyarakat. Hal tersebut yang membuat interaksi sosial siswa tidak berkembang secara optimal.

Mendukung perkembangan yang optimal siswa sekolah mempunyai wadah untuk berlatih untuk berkomunikasi dan kontak sosial yang sesuai dengan norma-norma yang berlaku diantaranya bimbingan dan konseling. Bimbingan dan konseling merupakan upaya yang dilakukan ahli dalam mengembangkan potensi siswa (Marimbun, 2021, 2019), Menurut Permendikbud 111 tahun 2014 bimbingan dan 
konseling merupakan suatu upaya sistematis, objektif, logis, dan berkelanjutan serta terprogram yang dilakukan oleh konselor atau guru Bimbingan dan Konseling untuk memfasilitasi perkembangan siswa/ konseli untuk mencapai kemandirian dalam kehidupannya.

Bimbingan dan konseling memiliki banyak program layanan dalam mengembangkan interaksi sosial siswa melalui layanan bimbingan dan konseling baik dalam setting individu, kelompok dan klasikal. hal ini didasari oleh beberapa hasil penelitian yang dilakukan oleh Mirahmadi \& Alamdarloo, (2016) penelitian yang berjenis eksperimen pada siswa yang mengalami gangguan dis abilitas sosial. Adapun hasil penelitian tersebut membuktikan keefektifan dalam mengurangi disabilities pada siswa perempuan. Setiawan \& Lianawati, (2020) dalam penelitiannya menjelaskan bahwa play therapy dalam kelompok kecil dapat meningkatkan interaksi sosial siswa. Oleh karena itu, pengabdian ini menekankan pada setting klasikal.

Bimbingan dan konseling banyak terdapat teknik dalam melaksanakan layanan dalam bentuk klasikal diantaranya play therapy. Play therapy merupakan salah satu sarana yang diberikan kepada anak atau remaja dengan pemanfaatan permainan sebagai media yang efektif untuk mengekspresikan dan mengeksplorasi dirinya dalam mencapai pertumbuhan dan perkembangan yang optimal. Menurut Geldard et al. (2016:267) bahwa media yang efektif untuk meningkatkan kemampuan berinteraksi sosial bagi remaja awal yaitu permainan (game) yang akan digunakan untuk berinteraksi dengan lingkungan. Karena bermain bukan hanya sesuatu aktivitas yang menyenangkan, namun terkandung nilai terapeutik.

Berdasarkan penjelasan pada di atas dan fenomena yang terjadi di lapangan, oleh karena itu perlu mengadakan penelitian yang berjudul "Penerapan Play Therapy dalam mengembangkan Interaksi sosial siswa di SMP N 8 Kota Jambi".

\section{METODE}

Pada kegiatan pelaksanaan PKM ini menggunakan setting klasikal dengan menggunakan play therapy dalam mengembangkan interaksi sosial siswa melalui metode berikut:

1. Metode Sosialisasi

Melalui metode ini dilakukan proses penanaman atau transfer kebiasaan pada satu generasi kepada generasi berikutnya bisa melalui bentuk individual, kelompok dan masyarakat. Metode ini digunakan untuk memberi beberapa penjelasan tentang interaksi sosial dan panduan play therapy, serta jejak pendapat.

2. Metode Play therapy

Metode ini dikembangkan dengan dasar konsep yang telah matang, pada metode ini membantu melatih siswa dalam rangka mencegah dan mengatasi hambatanhambatan, serta membantu siswa mencapai tugas perkembangannya. Melalui metode ini siswa dilatih untuk berkomunikasi dengan menggunakan bahasa yang baik dalam melakukan kerja sama dan melatih kontak sosial antar siswa. 
Rancangan evaluasi dalam PKM ini menggunakan instrumen untuk melihat kondisi interaksi sosial siswa sebelum pelaksanaan PKM ini. Kemudian dilakukan pemberian PKM ini dengan melihat berdasarkan indikator tingkat ketercapaian dan kesesuaian tahapan yang telah ditetapkan. Kemudian dilakukan pengumpulan data ulang untuk melihat ketercapaian perkembangan interaksi sosial siswa yang telah ditetapkan.

\section{HASIL DAN PEMBAHASAN}

Kegiatan pengabdian ini dengan judul Penerapan Play Therapy dalam mengembangkan Interaksi sosial siswa di SMP N 8 Kota Jambi". Tim tertarik untuk melakukan kegiatan pengabdian kepada masyarakat ini karena dipandang perlu perkembangan bimbingan dan konseling terutama dalam mengembangkan interaksi sosial siswa sangat dinamis sehingga perlu dikembangkan melalui play therapy melalui pendekatan ini yang dilatih kepada siswa dalam interaksi meningkatkan interaksi sosialnya.

Adanya pendekatan Play therapy dalam bimbingan kelompok sehingga dapat menambah pengetahuan siswa mengenai interaksi sosial siswa khususnya dalam setting kelompok bimbingan kelompok. Tim pengabdian kepada masyarakat bekerja sama dengan guru BK SMP N 8 Kota Jambi. Hasil akhir kegiatan ini diharapkan guru BK terampil dalam melaksanakan bimbingan kelompok dengan pendekatan play therapy dan bagi siswa diharapkan mengembangkan interaksi sosial secara positif baik dari segi perilaku dan dalam berkomunikasi.

Berdasarkan hasil analisis kebutuhan, melihat perkembangan zaman guru perlu memperhatikan interaksi sosial pada siswa yang positif. Lembaga Pengabdian Kepada Masyarakat mempunyai tugas menyelenggarakan kegiatan pengabdian kepada masyarakat dan ikut mengusahakan sumber daya yang diperlukan. Untuk menyelenggarakan tugas tersebut lembaga ini mempunyai fungsi antara lain untuk, Mengamalkan ilmu pengetahuan, Meningkatkan relevansi program Universitas Jambi sesuai dengan kebutuhan masyarakat, Membantu masyarakat dalam melaksanakan pembangunan, Melaksanakan pengembangan pola dan konsepsi pembangunan Nasional, Wilayah dan atau Daerah melalui kerjasama antara Perguruan Tinggi atau badan lain baik dalam maupun di luar negeri.

Universitas Jambi dalam bidang pengabdian masyarakat, sudah banyak melaksanakan kegiatan pengabdian kepada masyarakat. Kegiatan tersebut ada yang bersifat nasional dan ada juga yang bersifat institusional. Kegiatan pengabdian masyarakat yang telah dilaksanakan pada masa lalu umumnya di danai oleh hibah dari DIKTI, Bantuan Luar negeri maupun oleh DIPA Universitas itu sendiri DIPA-PNP atau DIPA-RM (BOPTN), DIPA PNBP dan sejenisnya. Di samping itu kegiatan pengabdian masyarakat melalui kerja sama dengan pemerintah daerah, instansi Dinas Pendidikan, instansi dinas social, instansi badan BKKBN, semua itu di fasilitasi ataupun di danai oleh instansi-instansi tersebut.

Hasil dan luaran yang dicapai dalam pengabdian ini menyesuaikan apa yang dirumuskan dan luaran yang diharapkan dari hasil pengabdian ini tentang Penerapan Play Therapy dalam mengembangkan Interaksi sosial siswa di SMP N 8 Kota Jambi. Pada 
Penerapan play therapy.......- Rasimin, Affan Yusra

saat identifikasi masalah: 1) Masih ditemukan siswa dalam berinteraksi dengan teman sebaya ataupun guru masih mengeluarkan kata-kata kurang enak di dengar; 2) Masih ditemukan siswa dalam berinteraksi dengan teman sebaya dalam kontak sosial siswa terkadang terdapat yang melanggar batas;3)Permainan pernah digunakan dalam layanan klasikal namun itu hanya sebatas penghilang kejenuhan dalam melakukan layanan klasikal.

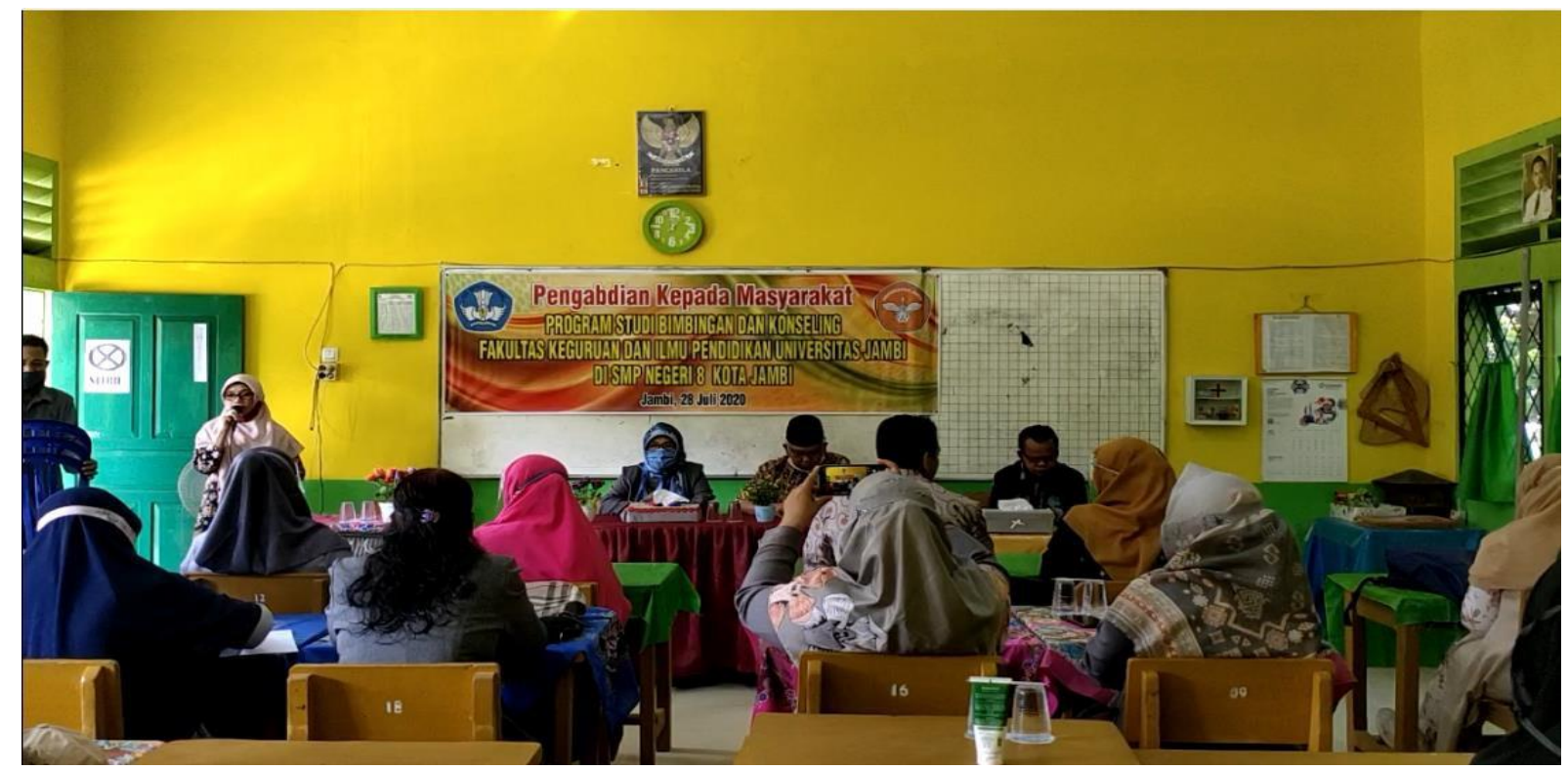

Gambar 1. Pertemuan Tim Binaan

Pertemuan kami didampingi oleh kepala sekolah untuk mewakili dalam menjelaskan dan Koordinator guru bimbingan dan konseling yang akan mengarahkan kami selama kegiatan di SMPN 8 Kota Jambi. Berdasarkan hasil identifikasi dan tujuan yang diharapkan dalam pengabdian ini telah tercapai dengan baik dibuktikan dengan hasil pengabdian yang dapat dijabarkan sebagai berikut:

\section{Mengembangkan Interaksi Sosial Siswa SMPN 8 Kota Jambi}

Pengabdian ini dibentuk sesuai rancangan untuk meningkatkan pengetahuan siswa 8 b kami mengadakan workshop sederhana diruagan kelas seperti terlihat pada foto di bawah ini:
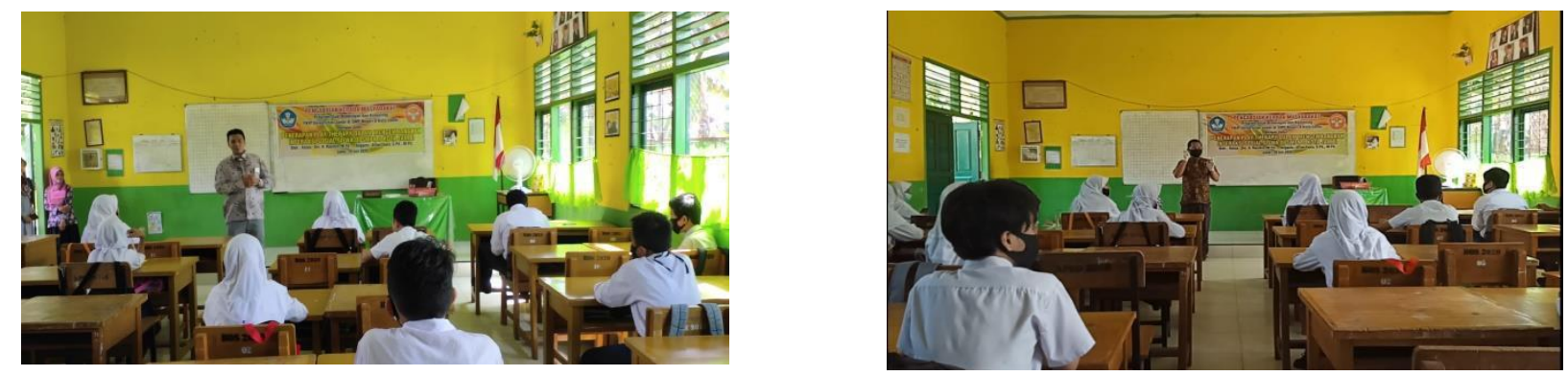


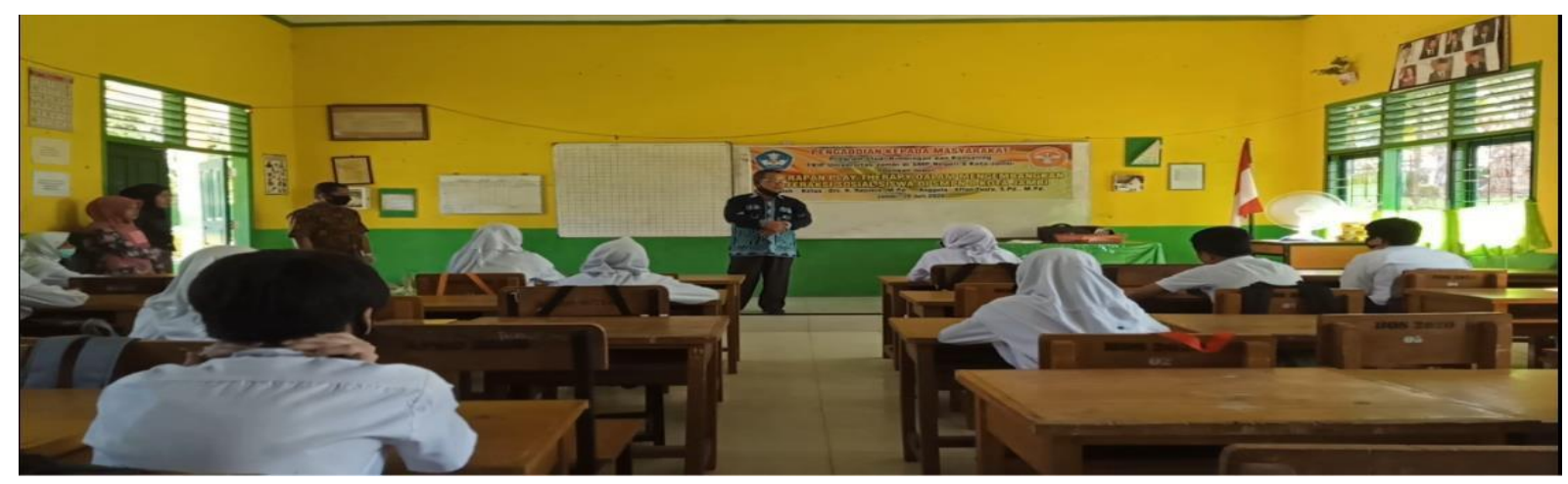

Gambar 2. Pemberian materi interaksi sosial

\section{Metode Play therapy}

Metode play therapy yang digunakan dalam pembinaan siswa dalam workshop ini merupakan fokus untuk mengembangkan interaksi sosial yang dimiliki oleh siswa yang berada di SMPN 8 Kota Jambi. Dalam hal ini FGD yang dilakukan untuk memberikan keleluasaan bagi siswa untuk bertanya dan mempraktekannya seperti foto dibawah ini:
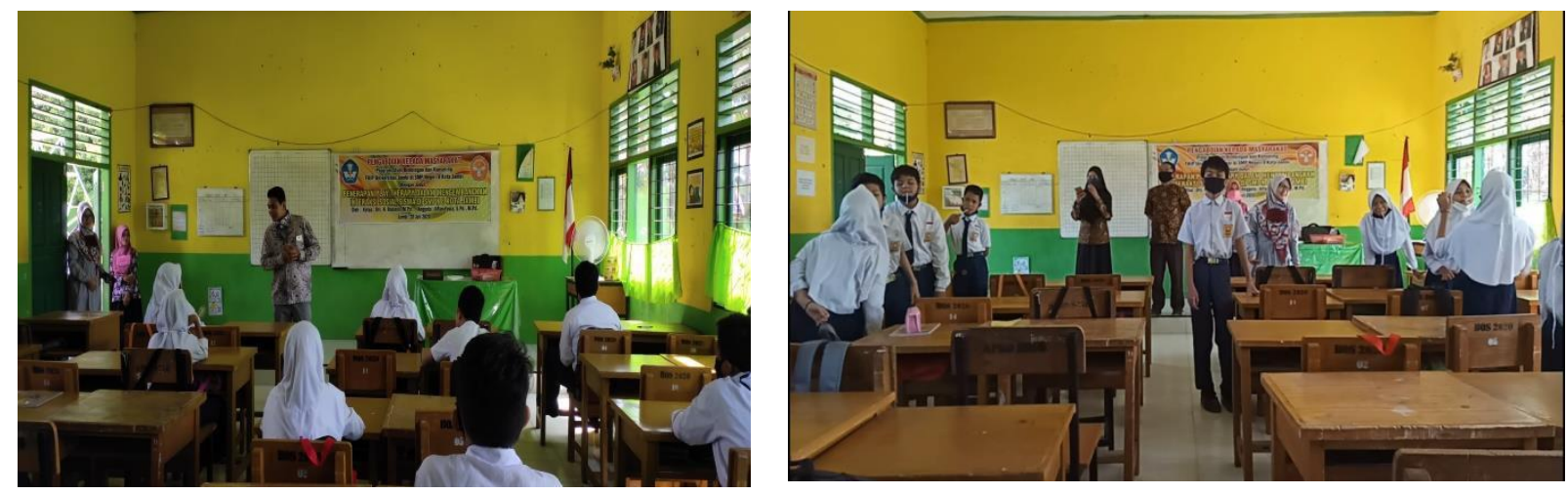

Gambar 3. Materi play therapy

\section{Metode play therapy dalam mengembangkan interaksi sosial}

PKM diperoleh gambaran interaksi sosial siswa kelas VIII SMP N 8 Kota Jambi. Interaksi sosial merupakan suatu hubungan antar sesama individu maupun kelompok yang menghasilkan suatu proses pengaruh mempengaruhi untuk mencapai kepentingan dan tuntutan kehidupan.

Interaksi sosial yang dimaksud dalam penelitian ini adalah interaksi sosial antar teman sebaya ditinjau dari bentuk-bentuk interaksi sosial yang meliputi kerjasama, akomodasi, asimilasi, persaingan. Siswa yang memiliki interaksi sosial yang rendah dan tidak diantisipasi sesuai kebutuhannya akan berdampak terhadap aspek perkembangan sosialnya di lingkungan sekolah, keluarga maupun masyarakat serta berdampak pada hasil belajar siswa di sekolah. Siswa yang memiliki interaksi sosial yang rendah apabila tidak mampu bekerjasama, tidak mampu menyesuaikan, tidak mampu berinteraksi dengan baik, tidak dapat mengontrol emosi diri, tidak mampu berempati, tidak mampu mentaati aturan serta tidak mampu menghargai orang lain. 
Penjabaran hasil interaksi sosial per indikator dalam penelitian ini, yakni sebagai berikut :

a. Indikator Kerjasama

Kerjasama merupakan kegiatan yang dilakukan oleh siswa secara bersama-sama antar individu dan kelompok dalam mengerjakan suatu aktivitas yang menyangkut pembelajaran di dalam kelas yang di tugaskan oleh guru atau kesadaran dari diri siswa untuk mengerjakan aktivitas tersebut.

Berdasarkan hasil PKM tersebut yang menunjukkan terjadinya perkembangan interaksi sosial siswa yakni indikator kerjasama setelah diberikan sosialisasi menggunakan play therapy. Hal ini sesuai dengan teori yang diungkapkan oleh Geldard, et al (2016:383) bahwa permainan dapat digunakan oleh konselor untuk membantu anak melatih keterampilan sosial seperti kerjasama, kolaborasi dan melatih respon yang tepat terhadap kekecewaan, kemunduran, kegagalan dan keberhasilan. Sejalan dengan pendapat Eliasa (dalam Loban et al., 2017) yang menemukan bahwa permainan (games) dapat membantu meningkatkan kerjasama dan kemampuan sosial setiap peserta layanan. Keterampilan sosial yang dilakukan bersamaan dengan permainan dapat merangsang perilaku sosial yang termasuk dalam unsur interaksi sosial secara positif (Barakova \& Emilia dalam Andriati, 2016:128).

b. Indikator Akomodasi

Berdasarkan kegiatan PKM tersebut menunjukkan bahwa, pada kelas sosialisasi interaksi sosial indikator akomodasi tidak mengalami peningkatan yang sangat berarti. Hal ini mungkin terjadi karena beberapa faktor seperti play therapy belum dirasakan manfaatnya bagi peserta layanan karena terdapat beberapa hambatan yakni pada saat pelaksanaan berlangsung ruangan multimedia yang dipakai akan digunakan oleh pihak sekolah secara mendadak karena baru ditunjuk bahwa sekolah SMP N 8 Kota Jambi sebagai pengisi paduan suara dalam memperingati hari anak sedunia. Sehingga, durasi pemberian peserta layanan harus dipercepat atau dipersingkat.

Ketidaktercapaian tujuan pelaksanaan peserta layanan tersebut terjadi karena beberapa kendala yakni ketersediaan waktu yang tidak sesuai dengan durasi waktu yang telah ditentukan sehingga terkesan mendesak dan siswa belum sepenuhnya memahami serta merasakan manfaat dari play tharapy. Suwarjo \& Eliasa (2011:20) mengungkapkan bahwa apabila waktu tatap muka tidak mencukupi kemudian permainan terpotong ditegah jalan, maka akan menimbulkan kekecewaan bersama dan tujuan permainan tidak tercapai.

c. Indikator Asimilasi

Asimilasi adalah perilaku yang ditunjukkan oleh siswa untuk mengurangi perbedaan- perbedaan pendapat, kebiasaan, yang terjadi antar individu atau kelompok untuk mempertinggi kesatuan tindak dan sikap dengan memperhatikan kepentingan dan tujuan bersama di dalam kelas.

Hasil penelitian ini sesuai dengan teori yang diungkapkan oleh Geldard, et al (2016:379) bahwa permainan merupakan hal yang menyenangkan dan juga membantu anak berkembang secara fisik, kognisi, emosi dan sosial. Kemudian diperkuat oleh pendapat Loban, dkk (2017:60) yang menyatakan bahwa bermain 
memfasilitasi proses asimilasi, memperkuat dan mengonsolidasikan pengetahuan, mempengaruhi perkembangan dan kematangan kepribadian. Pada saat bermain, terapis menggunakan permainan, mainan dan media yang lainnya yang berbedabeda yakni untuk membantu anak mengekspresikan emosinya, sehingga anak memiliki kesempatan untuk mengatasi emosi-emosinya secara tepat dalam lingkungan yang aman (Venter dalam Putri, 2014:818)

\section{d. Indikator Persaingan}

Persaingan adalah usaha yang dilakukan individu untuk mendapatkan nilai atau prestasi (penghargaan atau peringkat) di dalam kelas. Hasil penelitian tersebut didukung oleh teori Reid \& Schafer (dalam (Hatiningsih, 2013:339) yang menyatakan bahwa play therapy sangat membantu anak untuk meningkatkan konsentrasi karena dalam permainan anak belajar untuk melatih perkembangan motorik, sensory, kognitif dan konsentrasi. Sejalan dengan pandangan Rusmana (dalam Suwarjo \& Eliasa, 2011:5) bahwa dalam bermain individu cenderung memiliki toleransi frustrasi yang cukup, pengujian realitas untuk menerima batasan-batasan dalam berperilaku, bagaimana kesabaran dipakai, hukum antrean, bergiliran, patuh dengan aturan permainan dan siap menerima kekalahan.

Interaksi sosial siswa pada indikator persaingan meningkat dikarenakan pemberian peserta layanan play therapy dengan setting klasikal, mereka benarbenar fokus dan konsentrasi terhadap layanan atau kegiatan yang sedang mereka tempuh sehingga mereka tidak terusik dengan keadaan lingkungan sekitar dan dapat menerapkan dalam kehidupan sehari-hari. Sehingga siswa dapat merasakan bagaimana seharusnya persaingan yang sehat/ baik dan mampu menerima setiap kekalahan dan mengakui keberhasilan orang lain.

\section{Kesimpulan}

Berdasarkan hasil pembinaan yang dilakukan dapat disimpulkan bahwa hasil dari pengembangan interaksi sosial, siswa memperoleh pengetahuan yang baru mengenai pentingnya interaksi sosial dan hasil dari kegiatan PKM ini juga terlihat dalam praktik dan workshop siswa sangat tertarik dengan metode ini karena dalam metode ini tidak hanya menekankan pada pembentukan dinamika interaksi sosial namun juga menekankan pada membangun dinamika anggota kelas sehingga dalam pelaksanaannya peserta layanannya memperoleh kemampuan dinamika dalam mengembangkan interaksi sosial.

\section{REFERENSI}

Dwistia, H., Latif, S., \& Widiastuti, R. (2013). Hubungan Interaksi Sosial Peserta Didik Dengan Prestasi Belajar. Bimbingan Dan Konseling, 1-12.

Haas, M. De, Aroyo, A. M., Brain, R., Barakova, E., Design, I., Haselager, W., \& Smeekens, I. (2016). The Effect Of A Semi-Autonomous Robot On. IEEE, 376-381.

Hatiningsih, N. (2013). Play Therapy Untuk Meningkatkan Konsentrasi Pada Anak Attention Deficit Hyperactive Disorder (AdHD). Jipt, 01(02), 324-342. 
Penerapan play therapy.......- Rasimin, Affan Yusra

Katrhhryn, G., David, G., \& Rebecca, F. Y. (2016). Konseling Anak-Anak (B. Sarwiji (ed.); 4th ed.). PT.

Loban, M. N., Wibowo, M. E., \& Purwanto, E. (2017). Jurnal Bimbingan Konseling Model Bimbingan Kelompok menggunakan Games untuk Meningkatkan Hubungan Interpersonal Siswa Abstrak. Jurnal Bimbingan Konseling, 6(1), 54-61.

Marimbun. (2021). Meningkatkan Minat Membaca Mahasiswa Melalui Bimbingan Kelompok Topik Tugas. Jurnal KOPASTA, 8(1), 54-65. https://www.journal.unrika.ac.id/index.php/kopastajournal/article/view/2978

Marimbun, M. (2019). Minat Membaca dan Implementasinya dalam Bimbingan dan Konseling. ENLIGHTEN: Jurnal Bimbingan Konseling Islam, 2(2), 74-84. https://doi.org/10.32505/ENLIGHTEN.V2I2.1361

Marimbuni, M., Syahniar, S., \& Ahmad, R. (2017). Kontribusi Konsep Diri dan Kematangan Emosi Terhadap Penyesuaian Diri Siswa dan Implikasinya Dalam Bimbingan Dan Konseling. Insight Jurnal Bimbingan Konseling, 6(2), 165-175. https://doi.org/10.21009/insight.062.05

Mirahmadi, Z., \& Alamdarloo, G. H. (2016). The Effectiveness of Group Play Therapy on Social Skills of Female Students With Intel-lectual Disability. In Physical Treatments (Vol. 6, Issue 2).

Pendidikan, M., Kebudayaan, D. A. N., \& Indonesia, R. (2014). Peraturan menteri pendidikan dan kebudayaan republik indonesia nomor 111 tahun 2014.

Putri, D. A. W. M. (2014). Gestalt play therapy untuk menangani masalah penyesuaian sosial : studi kasus pada siswa taman. seminar nasional riset inovatif.

Setiawan, D., \& Lianawati, A. (2020). Group Play Therapy efektif meningkatkan interaksi sosial teman sebaya di PKBM Mandiri Surabaya. Electronic) Pusat Kajian BK Unindra-IKI, 257(2), 257-263. https://doi.org/10.26539/teraputik.42433

Sumarno, H. (2008). Ilmu Pengetahuan Sosial (Widiyantoro (ed.); 1st ed.). Solo Tiga Serangkai Pustaka Mandiri.

Suwarjo, \& Eliasa. (2011). Permainan (Games) dalam Bimbingan dan Konseling. Paramitra Publishing.

Witarsa, R., Hadi, R. S. M., Nurhananik, \& Haerani, N. R. (2018). Pengaruh penggunaan gadget terhadap kemampuan interaksi sosial siswa sekolah dasar. pedagogik, vi, 9-20. 
